\title{
Penerapan Metode REBA dan EFD dalam Perancangan Stasiun Kerja Ergonomis pada Proses Pencetakan Produk Tahu
}

\author{
(Studi Kasus UKM Tahu Sendang)
}

\author{
Rinda Setyowati, Jazuli, Ratih Setyaningrum \\ Program Studi Teknik Industri Universitas Dian Nuswantoro Semarang \\ Jl. Nakula I No. 5-11, Semarang, Jawa Tengah, 50131 \\ Email : rindaasetyo@gmail.com
}

\begin{abstract}
The design of an ergonomic working system in the company of either manufacturing or service requires ergonomic methods in its application to help people adjust the work system with psychological and physiological factors, the goal is to avoid illness or accidents due to work and can increase comfort and work productivity. SME Know Sendang is one of the small-scale manufacturing companies engaged in the production of tofu products that experienced problems in the production process associated with high rates of work-related pain, especially spinal complaints experienced by employees on the production floor. The study started by measuring the level of potential work-related illness using the Neat Entire Body Assesment (REBA) method and the result of 3 high-risk action actions of $94 \%$ of potential workers could experience back pain due to traditional and non-ergonomic work positions especially on the process move the know to the printout. Work station improvements are designed using the Ergonomic Function Deployment (EFD) method to obtain ergonomic and ergonomic seating designs using anthropometric measurements of human working positions. The anthropometry calculation results show that the height of the ergonomic seating height is $105 \mathrm{~cm}$, the length of the printed table is $1500 \mathrm{~cm}$, the height of the printed table is $53 \mathrm{~cm}$ using the high anthropometric dimension of the knee and the height of the $65 \mathrm{~cm}$ valve using the height of the sitting elbow. The calculation validation was performed by calculating the final REBA value and obtained the value of action 1 with the low potency level and the potential backbone pain decreased to $20 \%$.
\end{abstract}

Keywords: Work Station Design, Ergonomic Work Position, REBA, EFD

\begin{abstract}
Abstrak
Perancangan suatu sistem kerja secara ergonomis pada perusahaan baik manufaktur ataupun jasa membutuhkan metode-metode ergonomi dalam penerapannya untuk membantu manusia menyesuaikan sistem kerja tersebut dengan faktor psikologis dan fisiologisnya, tujuannya adalah untuk menghindari sakit ataupun kecelakaan akibat kerja serta dapat meningkatkan kenyamanan dan produktivitas kerja. UKM Tahu Sendang merupakan salah satu perusahaan manufaktur skala kecil bergerak pada produksi produk tahu yang mengalami permasalahan pada proses produksi terkait tingginya angka sakit akibat kerja terutama keluhan tulang belakang yang dialami pegawai di lantai produksi. Penelitian dimulai dengan mengukur tingkat potensi sakit akibat kerja dengan menggunakan metode Rapi Entire Body Assesment (REBA) dan diperoleh hasil action 3 level resiko tinggi sebesar 94\% potensi pekerja dapat mengalami sakit tulang punggung oleh karena posisi kerja yang masih tradisional dan tidak ergonomis terutama pada proses memindahkan tahu ke tempat cetakan. Perbaikan stasiun kerja dirancang dengan metode Ergonomic Function Deployment (EFD) untuk mendapatkan desain tempat duduk yang sesuai kebutuhan dan ergonomis dengan menggunakan pengukuran antropometri posisi kerja manusia. Hasil perhitungan antropometri menunjukkan data tinggi mata duduk yang ergonomis yaitu untuk tinggi bak penampung adalah $105 \mathrm{~cm}$, panjang meja cetakan adalah $1500 \mathrm{~cm}$, tinggi meja cetakan $53 \mathrm{~cm}$ menggunakan dimensi antropometri tinggi lutut dan tinggi valve $65 \mathrm{~cm}$ menggunakan tinggi siku duduk. Validasi perhitungan dilakukan dengan menghitung nilai REBA akhir dan diperoleh nilai action 1 dengan level potensi rendah dan potensi sakit tulang punggung menurun menjadi $20 \%$.
\end{abstract}

Kata kunci: Perancangan Stasiun Kerja, Posisi Kerja Ergonomis, REBA, EFD 


\section{Pendahuluan}

Tahu adalah produk makanan asal China dan juga banyak digemari oleh masyarakat Indonesia karena memiliki cita rasa yang nikmat, bergizi tinggi dan harganya juga terjangkau. Di Indonesia, tahu sudah menjadi makanan yang sangat familier dikonsumsi oleh masyarakat kelas bawah maupun kelas atas. Proses pembuatan tahu banyak dilakukan di indutri kecil seperti Usaha Kecil dan Menengah (UKM). Agar UKM tetap bertahan perlu dilakukan perbaikan terus- menerus mulai dari proses sampai rancangan sistem kerja. Sistem kerja yang baik merupakan salah satu faktor terpenting dalam kemajuan UKM, dan merupakan kunci utama keberhasilan dalam rangka meningkatkan produktivitas dan efisiensi UKM serta mengurangi risiko cidera. Di Jawa Tengah ada sekitar 500 industri tahu yang sampai saat ini masih terus mengembangkan kapasitas produksinya. Diantaranya salah satu industry rumahan yang ada diSemarang yaitu UKM Tahu Sendang yang sampai saat ini masih berproduksi dengan pesanan tahu cukup banyak.

Pada proses produksi di UKM Tahu Sendang masih dilakukan dengan cara tradisional atau manual terutama pada proses memindahkan tahu ke tempat cetakan. Proses memindahkan tahu ke tempat cetakan yang umum dilakukan yaitu dengan hasil penyaringan sari tahu menjadi tahu ditempatkan di bak penampung. Kemudian di pindahkan satu per satu dengan menggunakan gayung ke tempat cetakan sampai penuh. Proses pemindahan tahu dari bak penampung seperti ini memerlukan tenaga besar dan waktu yang lama. Posisi pekerja membungkuk dan kurang sesuai ukurannya, hal ini berarti kondisi kerja tersebut tidak ergonomis dan akan menimbulkan para pekerja merasakan sakit di beberapa bagian tubuhnya.

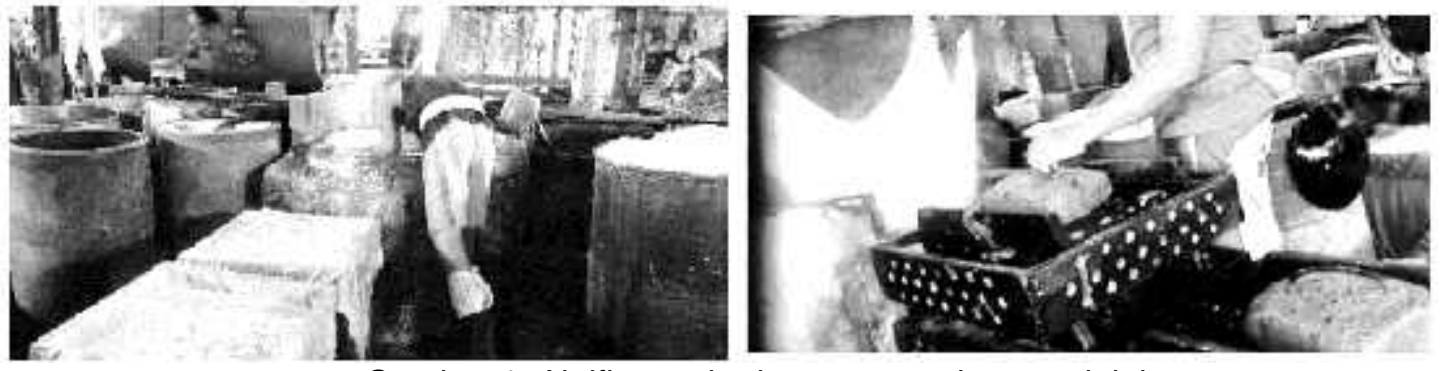

Gambar 1. Aktifitas pekerja menggunakan produk lama

Dari hasil wawancara dan pengisian kuesioner Nordic Body Map terhadap 15 responden pekerja dibagian ini ternyata kegiatan memindahkan tahu dari bak penampung ke tempat cetakan menimbulkan keluhan musculosketal dan kelelahan. Dilihat dari sisi keluhan musculosketal yaitu 94\% sakit pada punggung, 87\% sakit pada pinggang, $80 \%$ sakit pada bahu kanan dan lengan atas kanan, $60 \%$ sakit pada tangan kanan dan kaki kanan, $53 \%$ sakit pada lengan bawah kanan dan kaki kiri. Dari hasil kuesioner tersebut kemudian menganalisis postur awal dengan Rapid Entire Body Assessment (REBA) menunjukkan bahwa keluhan musculoskeletal yang dihasilkan pada skor Tabel A adalah 5, skor Tabel B adalah 7 dan skor Tabel $\mathrm{C}$ adalah 8, maka didapatkan hasil skor awal adalah 9 yang masuk dalam kategori action 3 yaitu perlu segera perbaikan untuk mengurangi resiko cidera pada pekerja.

Berdasarkan latar belakang tersebut, penulis ingin memperbaiki sistem kerja yang ada di UKM Tahu Sendang, yaitu dengan cara merancang meja produksi tahu dimana meja tersebut mempunyai bak penampung yang dapat mengalirkan tahu ke tempat cetakan sekaligus terdapat alat press tangan sederhana yang tentunya meja produksi tersebut memiliki aspek ergonomis.

\section{Metode Penelitian}

Penelitian ini menggunakan metode Ergonomic Function Deployment (EFD) dan Rapid Body Assesment (REBA). Metode EFD merupakan pengembangan dari Quality Function Deployment (EFD) [1] yaitu dengan menambahkan hubungan baru antara keinginan konsumen dan aspek ergonomi dari produk. Ergonomi didefinisikan sebagai studi tentang aspek-aspek manusia dalam lingkungan yang ditinjau secara anatomi, fisiologi, psikologi, engineering, manajemen dan desain atau perancangan [2]. Menurut Sutalaksana [3], ergonomi adalah suatu cabang ilmu yang sistematis untuk memanfaatkan informasi-informasi mengenai sifat, kemampuan dan keterbatasan manusia untuk merancang suatu sistem kerja sehingga orang dapat hidup dan bekerja pada sistem itu dengan baik, yaitu mencapai tujuan yang diinginkan melalui pekerjaan itu dengan efektif, aman, dan nyaman. Hubungan ini akan melengkapi 
bentuk matrik House of Quality yang juga menterjemahkan ke dalam aspek-aspek ergonomic yang diinginkan. Matrik House of Quality yang digunakn pada EFD dikembangkan menjadi matrik House of Ergonomic. Langkah-langkah metodologi penelitian yang dilakukan yaitu studi lapangan, identifikasi dan perumusan masalah, studi pustaka (studi kepustakaan) dan riset lapangan (observasi, kuisioner dan wawancara), atribut produk yang digunakan diturunkan dari aspek ergonomic, yaitu ENASE (Efektif, Nyaman, Aman, Sehat, dan Efisien). Sedangkan metode REBA adalah sebuah metode dalam bidang ergonomi yang digunakan secara cepat untuk menilai postur leher, punggung, lengan, pergelangan tangan, dan kaki seorang pekerja. Selain itu metode REBA memperhitungkan beban yang ditangani dalam suatu sistem kerja, couplingnya dan aktifitas yang dilakukan.

Metode REBA relatif mudah digunakan karena untuk mengetahui nilai suatu anggota tubuh tidak diperlukan besar sudut yang spesifik, hanya berupa range sudut. Pada akhirnya nilai akhir dari REBA memberikan indikasi level resiko dari suatu pekerjaan dan tindakan yang harus dilakukan atau diambil. Adapun resiko tersebut adalah musculoskeletal disorder. Aktivitas dengan tingkat pengulangan tinggi dapat menyebabkan kerusakan pada jaringan sehingga dapat menimbulkan rasa nyeri dan rasa tidak nyaman pada otot [4] Keluhan Muskuloskeletal atau gangguan otot rangka merupakan kerusakan pada otot, saraf, tendon, ligament, persendian, kartilago, dan discus invertebralis.Kerusakan pada otot dapat berupa ketegangan otot, inflamasi, dan degenerasi.Sedangkan kerusakan pada tulang dapat berupa memar, mikro faktur, patah, atau terpelintir [5].

Pengumpulan data dilakukan dengan menggunakan data kuesioner Nordic Body Map, Kuesioner Tingkat Kepentingan dan Kepuasan Konsumen, dan data anthropometri. Langkah selanjutnya pengolahan data Postur Awal REBA, Uji Statistik dan hasil anthropometri. Selanjutnya dilakukan analisis perancangan stasiun kerja dengan metode EFD dan REBA, kemudian dilakukan analisis hasil perancangan stasiun kerja pencetakan tahu dan diimplementasikan di lapangan. Bagian akhir penelitian ini adalah kesimpulan dan saran. Alur kegiatan penelitian ini dapat dilihat pada Gambar 1 berikut ini.

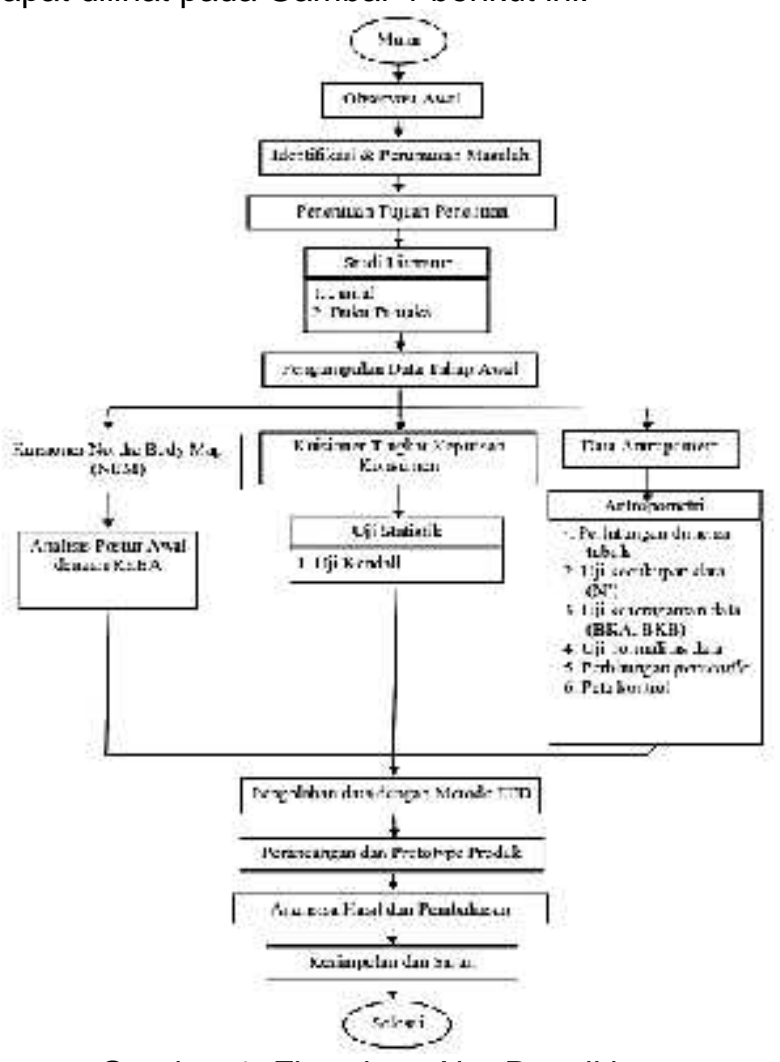

Gambar 1. Flowchart Alur Penelitian 


\section{Hasil dan Analisis}

\subsection{Pengumpulan Data}

a. Kuesioner NBM

Kuesioner ini berisi checklist bagian tubuh yang mengalami keluhan sakit pada saat melakukan pekerjaan. Dilihat dari sisi keluhan musculosketal yaitu $73 \%$ sakit pada bahu kanan, 94\% sakit pada punggung, 60\% sakit pada tangan kanan dan kaki kanan, $80 \%$ sakit pada lengan atas kanan $87 \%$ sakit pada pinggang, dan $53 \%$ sakit pada lengan bawah kanann pergelangan tangan kanan dan kaki kiri. Hal ini dikarenakan pekerjaan tersebut dilakukan secara berulang dalam jangka waktu yang lama. Dan posisi saaat melakukan pekerjaan tersebut juga membutuhkan konsentrasi yang tinggi.

b. Kuesioner Kepentingan dan Kepuasan Konsumen

Penyebaran kuesioner ini dilakukan kepada 15 responden untuk mendapatkan hasil skala tingkat kepentingan dan kepuasan terhadap variabel ENASE. Kuesioner ini dibuat berdasar daftar pernyataan yang sudah tercantum pada variable ENASE. Daftar pernyataan kuesioner tingkat kepentingan dan kepuasan dapat dilihat pada Tabel 1 berikut:

Tabel 1. Kuesioner Tingkat Kepentingan dan Kepuasan Konsumen

\begin{tabular}{|c|c|c|c|c|c|c|}
\hline \multirow{2}{*}{ No } & \multirow{2}{*}{ Pertanyaan Tingkat Kepentingan } & \multicolumn{5}{|c|}{ Kepentingan } \\
\hline & & STP & TP & $\mathrm{CP}$ & $\mathrm{P}$ & SP \\
\hline 1 & Meja rroduksi tahu mudah dalam pengoperasian & & & & & \\
\hline 2 & Meja oroduksi tahu memiliki tingkat kekuatan yang baik & & & & & \\
\hline 3 & Meja כroduksi tahu memiliki kapasitas yang maksimal & & & & & \\
\hline 4 & Meja rroduksi tahu memiliki desain produk yang ergonomis & & & & & \\
\hline 5 & Meja rroduksi tahu memiliki ukuran yang nyaman digunakan & & & & & \\
\hline 6 & Meja rroduksi tahu aman saat disunakan & & & & & \\
\hline 7 & Meja oroduksi tahu mengurangi keluhan muskuloskeletal & & & & & \\
\hline 8 & Meja jroduksi tahu memiliki kualitas produk yarg baik & & & & & \\
\hline 9 & Meja rroduksi tahu mudah dalam perawatan & & & & & \\
\hline 10 & Meja rroduksi tahu memiliki bahan baku yang kuat dan awet & & & & & \\
\hline \multirow{2}{*}{ No } & \multirow{2}{*}{ Pertanyaan Tingkat Kepuasan } & \multicolumn{5}{|c|}{ Kepuasan } \\
\hline & & STP & TP & $\mathrm{CP}$ & $\mathrm{P}$ & SP \\
\hline 1 & Meja rroduksi tahu mudah dalam pengoperasian & & & & & \\
\hline 2 & Meja Jroduksi tahu memiliki tingkat kekuatan yang baik & & & & & \\
\hline 3 & Meja Jroduksi tahu memiliki kapasitas yang maksinal & & & & & \\
\hline 4 & Meja rroduksi tahu memiliki desain produk yang ergonomis & & & & & \\
\hline 5 & Meja כroduksi tahu memiliki ukuran yang nүaman digunakan & & & & & \\
\hline 6 & Meja rroduksi tahu aman saat digunakan & & & & & \\
\hline 7 & Meja oroduksi tahu mengurangi keluhan muskuloskeletal & & & & & \\
\hline 8 & Meja roduksi tahu memiliki kualitas produk yarg baik & & & & & \\
\hline 9 & Meja rroduksi tahu mudah dalam perawatan & & & & & \\
\hline 10 & Meja rroduksi tahu memiliki bahan baku yang kuat dan awet & & & & & \\
\hline
\end{tabular}

\section{c. Data Anthropometri}

Adapun dimensi yang digunakan dalam perancangan produk adalah Tinggi Mata Duduk (TMD), Tinggi Siku Duduk (TSD), Tinggi Lutut (TL) dan Jangkaun Tangan (JT). Penulis menggunakn data antropometri Indonesia yang dapat dilihat pada Tabel 2 berikut ini.

Tabel 2. Data Antropometri

\begin{tabular}{|c|c|c|c|}
\hline TMD (cm) & TSD (cm) & TL (cm) & JT (cm) \\
\hline $\mathbf{1 0 7}$ & 70 & 48 & 78 \\
\hline $\mathbf{1 0 6}$ & 68 & 47 & 75 \\
\hline $\mathbf{1 0 5}$ & 67 & 46 & 74 \\
\hline $\mathbf{1 0 7}$ & 69 & 48 & 77 \\
\hline $\mathbf{1 0 5}$ & 68 & 49 & 78 \\
\hline $\mathbf{1 0 6}$ & 69 & 48 & 77 \\
\hline $\mathbf{1 0 8}$ & 65 & 49 & 78 \\
\hline $\mathbf{1 0 5}$ & 66 & 53 & 75 \\
\hline $\mathbf{1 0 6}$ & 67 & 53 & 77 \\
\hline $\mathbf{1 0 7}$ & 65 & 50 & 76 \\
\hline
\end{tabular}




\begin{tabular}{|c|c|c|c|}
\hline TMD (cm) & TSD (cm) & TL (cm) & JT (cm) \\
\hline $\mathbf{1 0 6}$ & 65 & 51 & 76 \\
\hline $\mathbf{1 0 6}$ & 68 & 49 & 78 \\
\hline $\mathbf{1 0 5}$ & 66 & 48 & 79 \\
\hline $\mathbf{1 0 7}$ & 67 & 52 & 76 \\
\hline $\mathbf{1 0 5}$ & 66 & 50 & 74 \\
\hline
\end{tabular}

\subsection{Pengolahan Data}

a. Postur Awal REBA

Hasil nilai REBA dapat dilihat pada Tabel 3 berikut:

Tabel 3. Rekapitulasi Perhitungan REBA

\begin{tabular}{|r|l|c|}
\hline No & Jenis Aktivitas & 9 \\
\hline 1 & $\begin{array}{l}\text { Mengambil dan meletakkan tahu dari bak } \\
\text { penampung }\end{array}$ & 7 \\
\hline 2 & Mengepress tahu & \\
\hline
\end{tabular}

\section{b. Uji Kendall}

Pada tahap ini sebelum data diolah menggunakan implementasi EFD, hasil kuisioner akan diuji terlebih dahulu dengan Uji Kendall. Berikut adalah hasil uji Kendall kuisioner perancangan meja tahu (Gambar 2).

\section{Kendall's W}

\begin{tabular}{|l|r|}
\multicolumn{2}{|c}{ Ranks } \\
\hline & Mean Rank \\
\hline P1 & 5.37 \\
P2 & 7.23 \\
P3 & 5.83 \\
P4 & 4.17 \\
P5 & 4.53 \\
P6 & 7.30 \\
P7 & 3.20 \\
P8 & 6.87 \\
P9 & 4.57 \\
P10 & 5.93 \\
\hline
\end{tabular}

$\Rightarrow$\begin{tabular}{|l|r|}
\multicolumn{2}{|c}{ Test Statistic } \\
\hline N & 15 \\
Kendall's ... & .251 \\
Chi-Square & 33.918 \\
df & 9 \\
Asymp. Sig. & .000 \\
\hline
\end{tabular}

a. Kendall's Coefficient of Concordance

Gambar 2. Output SPSS Uji Kendall

Hipotesis :

Ho: Responden tidak berasosisasi, atau responden tidak ada kesepakatan atau keselarasan dalam menilai ke sepuluh atribut. 
$\mathrm{Hi}$ : Responden berasosisasi, atau responden ada kesepakatan atau keselarasan dalam menilai ke sepuluh atribut.

Dasar pengambilan keputusan berdasarkan probabilitas:

Jika probabilitas $>0,05$, maka Ho diterima

Jika probabilitas $<0,05$, maka Ho ditolak

Keputusan :

Terlihat bahwa dalam kolom Asymp,Sig. adalah 0,000 artinya probabilitas lebih kecil atau dibawah 0,05 , maka Ho ditolak dan Hi diterima atau responden berasosisasi ada kesepakatan dan keselarasan dalam menilai ke sepuluh atribut dalam perancangan meja kerja tahu.

\section{c. Data Anthropometri}

Perancangan desain ini dilakukan dengan mempertimbangkan dan mengolah seluruh data yang diperoleh yakni mengenai kebutuhan konsumen target spesifikasi dan data antropometri. Berikut ini adalah pertimbangan penentuan dimensi dari produk yang akan dirancang.

Tabel 3. Data Anthropometri

\begin{tabular}{|l|c|c|c|c|}
\hline Kegunaan & Dimensi & Persentil & Nilai (cm) & $\begin{array}{c}\text { Ukuran Rancangan } \\
\text { (cm) }\end{array}$ \\
\hline $\begin{array}{l}\text { Tinggi meja bak } \\
\text { penampung }\end{array}$ & TMD & P5 & 104,49 & 105 \\
\hline $\begin{array}{l}\text { Tinggi bak } \\
\text { penampung }\end{array}$ & TSD & P5 & 64,47 & 65 \\
\hline Tinggi meja cetakan & TL & P50 & 49,40 & 50 \\
\hline Lebar meja cetakan & JT & P95 & 53,20 & 60 \\
\hline
\end{tabular}

\subsection{ANALISIS IMPLEMENTASI}

Pada tahap identifikasi kebutuhan konsumen didahului oleh pengumpulan data yang didapat dari kuesioner EFD. Pernyataan-pernyataan dalam kuesioner dibuat dengan mempertimbangkan hasil jawaban dan saran yang diberikan responden pada kuesioner awal Pada tahap menentukan tingkat kepentingan konsumen ditentukan dari kuesioner dimana responden diminta untuk memilih 5 kriteria jawaban yaitu sangat tidak penting, tidak penting, cukup penting, penting dan sangat penting. Kelima kriteria jawaban tersebut akan dinilai menggunakan skala Likert yang bernilai dari 1 sampai 5. Pada tahap menentukan tingkat kepuasan konsumen merupakan tanggapan konsumen mengenai sejauh mana suatu produk atau jasa dapat memenuhi kebutuhan konsumen, apakah sesuai dengan harapan konsumen atau tidak. Pada tahap menentukan goal (target) yaitu dengan menilai seberapa jauh peneliti ingin memenuhi kebutuhan konsumen dengan pertimbangan apakah kebutuhan konsumen tersebut dapat terpenuhi atau tidak.

Pada tahap menentukan rasio perbaikan (improvement ratio) untuk nilai yang semakin besar menunjukkan semakin besar tingkat perubahan yang harus dilakukan. Pada tahap menentukan titik jual (sales point) menunjukkan seberapa besar pengaruh pemenuhan kebutuhan konsumen terhadap produk. Pada tahap menghitung raw weight merupakan nilai tingkat kepentingan secara menyeluruh (overall importance) dari kebutuhan konsumen.

Pada tahap menghitung normalized raw weight merupakan nilai raw weight yang dibuat dalam skala 0 sampai 1 atau dalam persen. Pada tahap menentukan respon teknis ini berisi tentang penerjemahan selera konsumen dalam bentuk istilah teknis. Adapun karakterstik teknis pada alat ini dapat dilihat pada Tabel 4. 
Tabel 4. Karakteristik Teknis

\begin{tabular}{|l|l|l|}
\hline No & \multicolumn{1}{|c|}{ Tingkat Kepentingan } & \multicolumn{1}{c|}{ Karakteristik Teknis } \\
\hline 1 & $\begin{array}{l}\text { Meja produksi tahu mudah dalam } \\
\text { pengoperasian }\end{array}$ & $\begin{array}{l}\text { Terdapat valve untuk memindahkan dari bak } \\
\text { ke cetakan }\end{array}$ \\
\hline 2 & $\begin{array}{l}\text { Meja produksi tahu memiliki tingkat kekuatan } \\
\text { yang baik }\end{array}$ & $\begin{array}{l}\text { Menggunakan bahan yang kuat dan sendi } \\
\text { mati pada rangka utama produk }\end{array}$ \\
\hline 3 & $\begin{array}{l}\text { Meja produksi tahu memiliki kapasitas yang } \\
\text { maksimal }\end{array}$ & $\begin{array}{l}\text { Membantu pekerja menghasilkan produk } \\
\text { dengan lebih cepat }\end{array}$ \\
\hline 4 & $\begin{array}{l}\text { Meja produksi tahu memiliki desain produk } \\
\text { yang ergonomis }\end{array}$ & Pekerja nyaman dalam menggunakan \\
\hline 5 & $\begin{array}{l}\text { Meja produksi tahu memiliki ukuran yang } \\
\text { nyaman digunakan }\end{array}$ & produk \\
\hline 6 & Meja produksi tahu aman saat digunakan & Tidak menciderai pekerja \\
\hline 7 & $\begin{array}{l}\text { Meja produksi tahu mengurangi keluhan } \\
\text { muskuloskeletal }\end{array}$ & $\begin{array}{l}\text { Mengurangi pegal pada bagian tubuh yang } \\
\text { digunakan }\end{array}$ \\
\hline 8 & $\begin{array}{l}\text { Meja produksi tahu memiliki kualitas produk } \\
\text { yang baik }\end{array}$ & $\begin{array}{l}\text { Memperhatikan cara kerja produk dengan } \\
\text { maksimal }\end{array}$ \\
\hline 9 & Meja produksi tahu mudah dalam perawatan & Proses perawatan mudah dilakukan \\
\hline 10 & $\begin{array}{l}\text { Meja produksi tahu memiliki bahan baku yang } \\
\text { kuat dan awet }\end{array}$ & Awet dan tahan lama \\
\hline
\end{tabular}

Pada tahap menentukan target spesifikasi merupakan suatu hasil dari pengembangan karakteristik teknis yang didapat dari identifikasi kebutuhan konsumen. Berikut ini adalah tabel target spesifikasi yang akan dicapai dalam penelitian ini (Tabel 5)

Tabel 5. Target Spesifikasi

\begin{tabular}{|l|l|}
\hline Karakteristik Teknis & Target Spesifikasi \\
\hline $\begin{array}{l}\text { Terdapat valve untuk memindahkan dari bak ke } \\
\text { cetakan }\end{array}$ & $\begin{array}{l}\text { Valve dari bak penampung untuk } \\
\text { memindahkan tahu ke cetakan }\end{array}$ \\
\hline $\begin{array}{l}\text { Menggunakan bahan yang kuat dan sendi mati } \\
\text { pada rangka utama produk }\end{array}$ & $\begin{array}{l}\text { Stainless persegi 6x5 untuk rangka kokoh } \\
\text { dan bak menggunakan stainless tebal 2mm }\end{array}$ \\
\hline $\begin{array}{l}\text { Membantu pekerja menghasilkan produk } \\
\text { dengan lebih cepat }\end{array}$ & $\begin{array}{l}\text { Terdapat alat press sederhana sehingga 3/4 } \\
\text { lebih cepat }\end{array}$ \\
\hline Pekerja nyaman dalam menggunakan produk & $\begin{array}{l}\text { Desain produk memperhatikan kenyamanan } \\
\text { pekerja }\end{array}$ \\
\hline Tidak menciderai pekerja & Tidak berbahaya bagi pekerja \\
\hline $\begin{array}{l}\text { Mengurangi pegal pada bagian tubuh yang } \\
\text { digunakan }\end{array}$ & $\begin{array}{l}\text { Menggunakan dimensi yang ergonomis } \\
\text { sesuai postur tubuh pekerja }\end{array}$ \\
\hline $\begin{array}{l}\text { Memperhatikan cara kerja produk dengan } \\
\text { maksimal }\end{array}$ & Produk memiliki bentuk dan hasil yang baik \\
\hline Proses perawatan mudah dilakukan & Mudah dalam perawatan \\
\hline Awet dan tahan lama & Bahan baku kuat dan awet \\
\hline
\end{tabular}

Setelah menentukan aspek-aspek dari EFD, tabel-tabel tersebut di atas seluruhnya disusun dalam house of ergonomic seperti pada Gambar 3 berikut : 


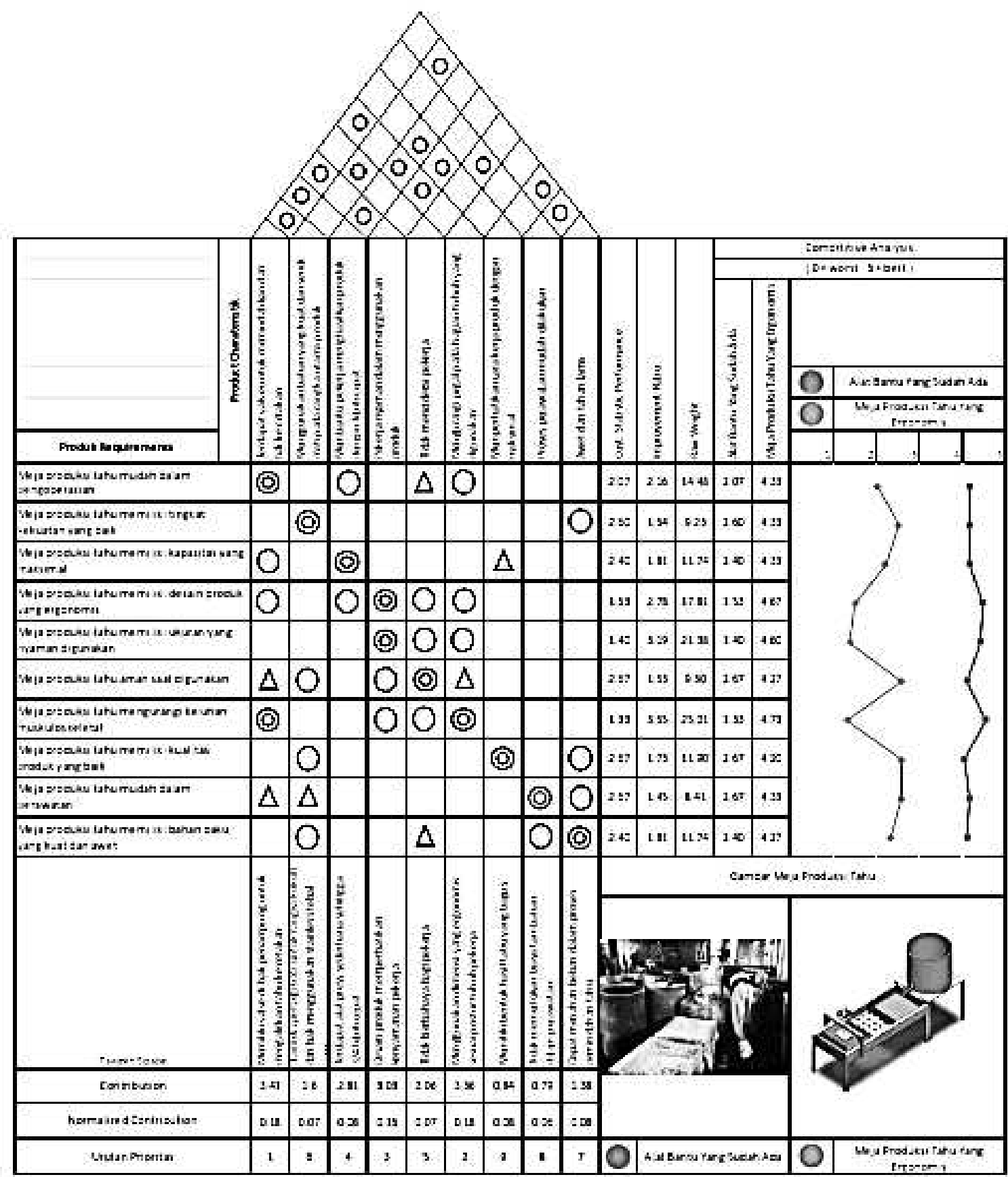

Gambar 3. House of Ergonomic

Setelah menentukan aspek-aspek dari EFD, dan penyusunan dalam house of ergonomic secara utuh. Kemudian dilakukan perancangan produk stasiun kerja pencetakan tahu ergonomis. Pada tahap perancangan meja pemindahan tahu, penentuan desain mempertimbangkan seluruh data yang didapat dari kebutuhan konsumen yang telah diolah menjadi target spesifikasi. Gambar 4 berikut merupakan desain dari meja pemindahan tahu ke cetakan 


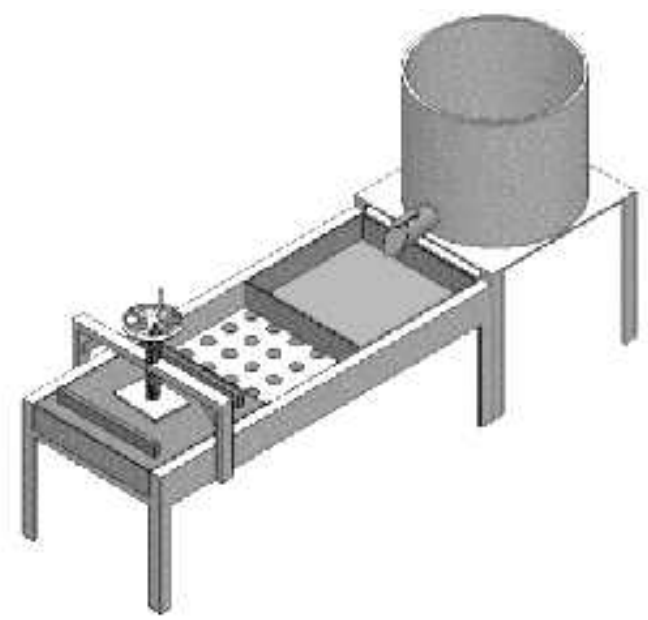

Gambar 4. Desain Stasiun Kerja Pencetakan Tahu

Tahapan selanjutnya setelah perancangan desain produk adalah pembuatan produk dan implementasi produk pada UKM Tahu Sendang. Dari tahap Implementasi didapatkan hasil yang dapat dilihat pada Gambar 5 sebagai berikut:

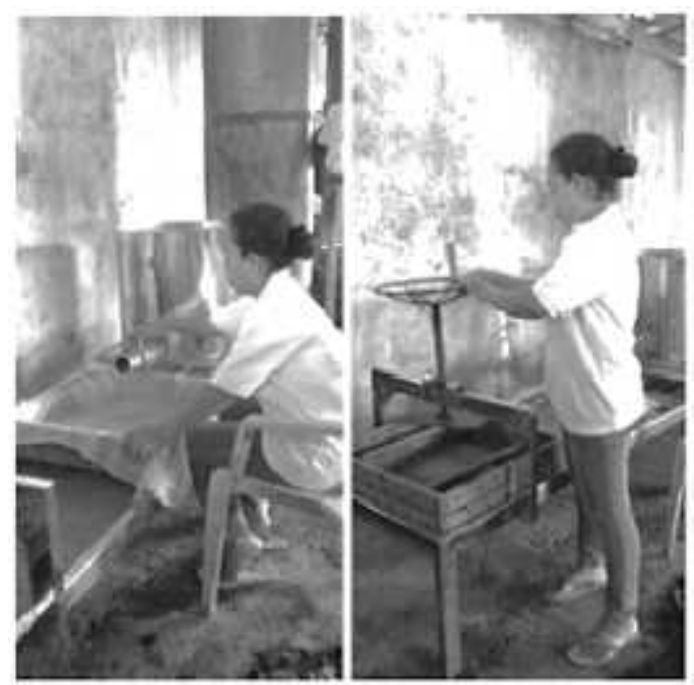

Gambar 5. Aktifitas pekerja menggunakan produk baru

Adapun hasil benchmarking NBM produk lama dan baru dapat dilihat pada Tabel 6 , sedangkan Benchmarking REBA produk lama dan baru dapat dilihat pada Tabel 7.

Tabel 6. Benchmarking NBM Produk Lama dan Produk Baru

\begin{tabular}{|c|c|c|}
\hline \multirow{2}{*}{ JENIS KELUHAN } & \multicolumn{2}{|c|}{ Jumlah } \\
\cline { 2 - 3 } & Sebelum & Sesudah \\
\hline Sakit/kaku di leher bagian atas & $47 \%$ & $33 \%$ \\
\hline Sakit/kaku di leher bagian bawah & $33 \%$ & $13 \%$ \\
\hline Sakit di bahu kiri & $40 \%$ & $13 \%$ \\
\hline Sakit di bahu kanan & $73 \%$ & $47 \%$ \\
\hline Sakit di punggung & $94 \%$ & $20 \%$ \\
\hline Sakit pada lengan atas kanan & $80 \%$ & $33 \%$ \\
\hline Sakit pada pinggang & $87 \%$ & $10 \%$ \\
\hline Sakit pada bokong & $27 \%$ & $20 \%$ \\
\hline Sakit pada pantat & $20 \%$ & $33 \%$ \\
\hline Sakit pada lengan bawah kiri & $20 \%$ & $13 \%$ \\
\hline Sakit pada lengan bawah kanan & $53 \%$ & $20 \%$ \\
\hline
\end{tabular}

Perancangan Stasiun Kerja Pencetakan Tahu Ergonomis Menggunakan Metode EFD Dan REBA (Studi Kasus UKM Tahu Sendang) (Rinda Setyowati) 


\begin{tabular}{|c|c|c|}
\hline \multirow{2}{*}{ JENIS KELUHAN } & \multicolumn{2}{|c|}{ Jumlah } \\
\cline { 2 - 3 } & Sebelum & Sesudah \\
\hline Sakit pada pergelangan tangan kanan & $53 \%$ & $27 \%$ \\
\hline Sakit pada tangan kiri & $20 \%$ & $13 \%$ \\
\hline Sakit pada tangan kanan & $60 \%$ & $40 \%$ \\
\hline Sakit pada paha kiri & $33 \%$ & $13 \%$ \\
\hline Sakit pada paha kanan & $40 \%$ & $13 \%$ \\
\hline Sakit pada lutut kiri & $27 \%$ & $7 \%$ \\
\hline Sakit pada lutut kanan & $27 \%$ & $13 \%$ \\
\hline Sakit pada pergelangan kaki kiri & $20 \%$ & $7 \%$ \\
\hline Sakit pada pergelangan kaki kanan & $20 \%$ & $7 \%$ \\
\hline Sakit pada kaki kiri & $53 \%$ & $7 \%$ \\
\hline Sakit pada kaki kanan & $60 \%$ & $13 \%$ \\
\hline
\end{tabular}

Tabel 7. Benchmarking REBA Produk Lama dan Produk Baru

\begin{tabular}{|c|c|c|}
\hline Posisi & $\begin{array}{c}\text { Score REBA } \\
\text { Awal }\end{array}$ & $\begin{array}{c}\text { Score REBA } \\
\text { Akhir }\end{array}$ \\
\hline Mengambil dan mindahkan tahu & 9 & 3 \\
\hline Mengepress tahu & 7 & 4 \\
\hline
\end{tabular}

Pada Tabel 7 diatas menunjukkan hasil score REBA awal adalah 9 dan 7 yang artinya masuk ke dalam Action Level 3 dengan level resiko tinggi kemudian setelah produk baru dibuat maka hasil score REBA akhir mengalami penurunan yaitu masuk dalam Action Level 1 yang artinya mungkin perlu diadakan perbaikan. Adapun perbandingan meja kerja tahu baru dan lama dapat dilihat pada Tabel 8.

Tabel 8. Perbandingan Meja Kerja Tahu Baru dan Lama

\begin{tabular}{|c|c|c|}
\hline Variabel & Produk Terdahulu & Produk Baru \\
\hline Efektif & $\begin{array}{l}\text { Memerlukan waktu yang lama untuk } \\
\text { memindahkan tahu ke tempat } \\
\text { cetakan dan mengepress tahu } \\
\text { dengan waktu proses } 21 \text { menit untuk } \\
\text { adonan } 5 \mathrm{~kg} \text {. }\end{array}$ & $\begin{array}{l}\text { Waktu proses mengalirkan tahu dan } \\
\text { mengepress tahu hanya memerlukan } \\
\text { waktu } 6 \text { menit dalam input adonan yang } \\
\text { sama dan hasil yang maksimal, artinya } \\
\text { waktu yang dibutuhkan lebih cepat } \\
\text { dibanding produk lama. }\end{array}$ \\
\hline Nyaman & $\begin{array}{l}\text { Desain tidak sesuai dengan dimensi } \\
\text { tubuh pekerja, sehingga pekerja } \\
\text { mengalami keluhan saat proses } \\
\text { berlangsung. Ditunjukkan pada hasil } \\
\text { NBM sakit dipunggung } 94 \% \text {. }\end{array}$ & $\begin{array}{l}\text { Produk yang telah dirancang sudah } \\
\text { sesuai dengan dimensi tubuh dari } \\
\text { pekerja, sehingga nyaman untuk } \\
\text { digunakan. Ditunjukkan pada hasil NBM } \\
\text { sakit dipunggung menurun menjadi } \\
20 \% \text {. }\end{array}$ \\
\hline Aman & $\begin{array}{l}\text { Alat yang sudah ada tergolong } \\
\text { masih belum aman untuk pekerja } \\
\text { karena tangan pekerja beresiko } \\
\text { melepuh dan kecelakaan kerja yang } \\
\text { dialami oleh pekerja. }\end{array}$ & $\begin{array}{l}\text { Meja telah dirancang hanya } \\
\text { mengalirkan tahu dengan bantuan valve } \\
\text { sehingga tangan pekerja tidak secara } \\
\text { langsung memegang tahu dan proses } \\
\text { ini sangat mengurangi kecelakan } \\
\text { pekerja. }\end{array}$ \\
\hline Sehat & $\begin{array}{l}\text { Kelelahan kerja dari hasil NBM sakit } \\
\text { pada punggung } 94 \% \text { yang di } \\
\text { lakukan terus menerus oleh pekerja } \\
\text { sehingga mengakibatkan sakit pada } \\
\text { tubuh. }\end{array}$ & $\begin{array}{l}\text { Karena adanya bantuan dari alat yang } \\
\text { dirancang dan desain yang sesuai } \\
\text { dengan dimensi tubuh pekerja, } \\
\text { sehingga hasil akhir NBM sakit pada } \\
\text { punggung mengalami penurunan } \\
\text { menjadi } 20 \% \text {. Hal ini menunjukkan alat } \\
\text { tidak menimbulkan keluhan kesehatan } \\
\text { bagi pekerja. }\end{array}$ \\
\hline
\end{tabular}




\begin{tabular}{|c|l|l|}
\hline Variabel & \multicolumn{1}{|c|}{ Produk Terdahulu } & \multicolumn{1}{c|}{ Produk Baru } \\
\hline Efesien & $\begin{array}{l}\text { Material yang terbuat dari semen } \\
\text { memerlukan harga yang lebih dan } \\
\text { alat tidak bisa dipindah-pindah. }\end{array}$ & $\begin{array}{l}\text { Harga lebih terjangkau dengan alat } \\
\text { yang full stainless yang terlihat lebih } \\
\text { menarik, bisa dipindah-pindah dan } \\
\text { menghasilkan tahu yang maksimal. }\end{array}$ \\
\hline
\end{tabular}

\section{Kesimpulan}

Berdasarkan penelitian yang dilakukan dengan menggunakan metode Ergonomic Function Deployment (EFD), variable yang menjadi prioritas perancangan produk yaitu memiliki valve di bak penampung untuk mengalirkan tahu ke cetakan dengan bobot 3,41. Menggunakan dimensi yang ergonomis dengan bobot 3,36 dan desain produk yang memperhatikan kenyamanan pekerja dengan bobot 2,84. Dimana didapatkan hasil sebuah perancangan meja kerja tahu yang ergonomis sesuai kebutuhan pekerja atau operator dengan tinggi meja menggunakan dimensi anthropometri tinggi mata duduk (TMD) sebesar $105 \mathrm{~cm}$, panjang meja cetakan menggunakan ukuran cetakan dan allowance sebesar $1500 \mathrm{~cm}$, tinggi meja cetakan menggunakan dimensi antropometri tinggi lutut $(T L) 53 \mathrm{~cm}$ dan tinggi valve menggunakan tinggi siku duduk (TSD) sebesar $65 \mathrm{~cm}$. Meja kerja tahu ini menggunakan stainless steel type 304 dan tebal 0,8 yang anti karat untuk tetap melindungi kualitas produk yang dihasilkan.

Hasil implementasi Nordic Body Map secara umum menunjukkan penurunan. Hasil yang signifikan ditunjukkan pada bagian punggung yang awalnya $94 \%$ para pekerja mengalami keluhan pada bagian tubuh tersebutberkurang menjadi 20\%. Sedangkan hasil analisis score REBA awal adalah 9 dan 7 yang artinya masuk ke dalam Action Level 3 dengan level resiko tinggi kemudian setelah stasiun kerja pencetak tahu dibuat maka hasil score REBA akhir mengalamai penurunan yaitu masuk dalam Action Level 1 yang artinya mungkin perlu diadakan perbaikan. Saran yang dapat diberikan oleh peneliti berdasarkan penelitian yang telah dilakukan adalah sebagai berikut: (1) Sebaiknya digunakan kursi yang sesuai dengan meja kerja supaya pekerja lebih nyaman dalam melakukan pekerjaan sehingga menunjang dalam proses pengerjaan pemidahan tahu dan (2) Dalam perancangan meja kerja tahu ini masih diperlukan analisis pengembangan lebih lanjut berkaitan dengan fungsi dan material yang digunakan, agar kedepannya didapatkan desain yang lebih baik lagi.

\section{Referensi}

[1] Ulrich \& Eppinger. 1995. Product Design and Development. NY: McGraw-Hill.

[2] Nurmianto, Eko. 2008. Ergonomi, Konsep Dasar dan Aplikasainya.Surabaya: Guna Widya.

[3] Sutalaksana, I. Z. 2006. Teknik Perancangan Sistem Kerja. Bandung. ITB.

[4] Occupational Health and Safety Council of Ontario (OHSCO). 2007. Prevention Musculoskeletal Tool Box USA:Ontario.

[5] Merulalia. 2010. Postur Tubuh Yang Ergonomis Saat Bekerja. Universitas Sumatera Utara. 